\title{
DIGITAL SURFACE AREA ASSESSMENT OF BROILER CHICKENS
}

\section{TADAYUKI YANAGI JÚNIOR ${ }^{1}$, ÉBERSON SILVA ${ }^{2}$, ROBERTO A. BRAGA JÚNIOR ${ }^{3}$, MARCOS A. LOPES ${ }^{4}$, FLÁVIO A. DAMASCENO ${ }^{5}$, GLEICE C. DE A. E SILVA ${ }^{6}$}

\begin{abstract}
Surface area (SA) of poultry is an important parameter for heat and mass transfer calculations. Optical approaches, such as the moiré technique (MT), are non-destructive, result in accuracy and speed gains, and preserve the object integrity. The objective of this research was to develop and validate a new protocol for estimating the surface area (SA) of broiler chickens based on the MT. Sixty-six Ross breed broiler chickens (twenty-seven male, thirty-nine female, ages spanning all growth phases) were used in this study. The dimensions (length, width and height) and body mass of randomly selected broiler chickens were evaluated in the laboratory. Chickens were illuminated by a light source, and grids were projected onto the chickens to allow their shape to be determined and recorded. Next, the skin and feathers of the chickens were removed to allow SA to be determined by conventional means. These measurements were then used for calibration and validation. The MT for image analysis was a reliable means of evaluating the three-dimensional shape and SA of broiler chickens. This technique, which is neither invasive nor destructive, is a good alternative to the conventional destructive methods.
\end{abstract}

KEYWORDS: image analysis, moiré technique, poultry.

\section{ESTIMATIVA DIGITAL DA ÁREA SUPERFICIAL DE FRANGOS DE CORTE}

RESUMO: A área superficial (AS) de aves é um importante parâmetro nos cálculos de transferência de calor e massa. Aproximações ópticas, tal como a técnica de moiré (MT), são não destrutivas, o que resulta em ganhos de precisão e velocidade, e preservam a integridade do objeto. O objetivo desta pesquisa foi desenvolver e validar um novo protocolo para estimativa da AS de frangos de corte com base na MT. Sessenta e seis frangos da linhagem Ross (vinte e sete machos e trinta e nove fêmeas, com idades abrangendo toda a fase de criação) foram usados neste estudo. As dimensões (comprimento, largura e altura) e a massa corporal dos frangos de corte, aleatoriamente selecionados, foram avaliadas em laboratório. As aves foram iluminadas por uma fonte de luz, e grades foram projetadas sobre as aves para permitir que as suas formas fossem determinadas e gravadas. Em seguida, a pele e as penas das aves foram removidas para permitir que a AS fosse determinada da maneira convencional. Estas medições foram usadas para a calibração e a validação. A MT para análise de imagens foi confiável para avaliar a forma tridimensional e a AS de frangos de corte. Esta técnica, não invasiva e não destrutiva, é uma boa alternativa em relação aos métodos destrutivos convencionais.

PALAVRAS-CHAVE: análise de imagem, técnica de moiré, avicultura.

\footnotetext{
${ }^{1}$ Doutor, Prof. Associado, Departamento de Engenharia, UFLA, Lavras - MG, yanagi@ deg.ufla.br.

${ }^{2}$ M.Sc., Professor, Departamento de Engenharia, FESP/UEMG, eberson_s@yahoo.com.br.

${ }^{3}$ Doutor, Prof. Associado, Departamento de Engenharia, UFLA, Lavras - MG, robbraga@ deg.ufla.br.

${ }^{4}$ Doutor, Professor, Departamento de Medicina Veterinária, UFLA, Lavras - MG, malopes@dmv.ufla.br. Bolsista do CNPq,

${ }^{5}$ Doutorando em Engenharia Agrícola, UFV, Viçosa - MG, flavio.damasceno@ufv.br.

${ }^{6}$ Eng $^{\mathrm{a}}$ Agrícola, Mestranda, Departamento de Engenharia, UFLA, Lavras - MG, gleicedche@ hotmail.com.

Recebido pelo Conselho Editorial em: 24-11-2010

Aprovado pelo Conselho Editorial em: 13-4-2011
} 


\section{INTRODUCTION}

It is necessary to know the surface area (SA) of broiler chickens to calculate heat and mass transfer between the chickens and their environment, which allows for the design of ventilation and evaporative cooling systems. The SA of broiler chickens is also used to make estimations that aid in poultry management, such as the amount of heat and humidity produced by the chickens (Yanagi Junior, 2002; Aerts et al., 2003; Yanagi Junior et al., 2006) and the increased body temperature of the animals under various conditions (Yanagi Junior et al., 2001). Routine methods of SA measurement are destructive and demand direct contact with the chickens. There is a need for a reliable and non-destructive method of poultry SA assessment.

Various methods based on image analysis can be used to determine the animals' features including their SA. These techniques have the advantage of being non-destructive (i.e., they do not require the sacrifice of the animals). Park et al. (2002) have suggested further efforts to improve machine vision in areas such as dimension, size, orientation and shape reproduction in, for example, poultry safety inspection. The development of non-destructive techniques for geometric measurement of biological specimens can be found in the literature (Prakoonwit and Benjamin, 2007; Kuo and Cheng, 2007; Costa et al., 2008). Acquisition, analysis and recovery of an object's surface characteristics can be obtained through various methods, including profilometric and optical techniques. However, optical methods are most often used because they do not require contact with the target, they are not destructive, and in most cases, they are fast and accurate (Hu, 2001).

Among the optical techniques, the moiré technique (MT) stands out because of its low cost. In addition, Asundi and Yung (1991) stated that the projection MT is a versatile tool that can be used for measuring the deformation of a plane and for recording the digital topographic contours, slopes, and curvature of an object.

$\mathrm{Hu}$ (2001) reported that MTs of shadow and projection are the most commonly used for profilometry, primarily due to the simplicity and speed of measurement of these techniques. Additionally, these techniques allow one to obtain better image contrast with clear fringe visualisation in a large range of usages.

Several accounts of MT applications can be found in the literature. In medicine, MT was used by Neugebauer and Windischbauer (1982) in research of human spine scoliosis, by Benoston (1997) in studies of obesity, by Keratron (2000) in studies of human cornea, and by Rahman et al. (2007) in studies of tympanic membrane perforation. In agriculture, Funnell and Decraemer (1998) used MT to study of the topography of cats tympanis. Braga et al. (2009) proposed a 3D protocol to obtain digital images using projection moiré. Shitakubo et al. (2003) used the projection of MT for modelling physical characteristics of fish. Costa et al. (2008) used the projection of MT for mapping the topographies of pieces of wood and of chickens. However, the mapping of chickens was done without any validation or relation to a meaningful variable, such as SA. In addition, Dal Fabbro et al. (2005) evaluated the projection moiré approach as a reliable tool in chickens' physical characterization, nevertheless suggested further work to overcome the errors caused by the feathers.

The present research proposes a reliable protocol to digitise broiler chickens through optical approaches using the projection MT. The proposed technique is validated against the conventional destructive method for measuring geometric properties of chickens, which is considered as a "gold standard". The chickens used covered all growth stages (age range of 1 to 42 days).

\section{MATERIALS AND METHODS}

\section{Animal management and data collection}

Sixty-six Ross breed broiler chickens were obtained from various commercial broiler houses located in the Barbacena region, state of Minas Gerais, Brazil. The ages of the broiler chickens ranged from 1 to 42 days. The chickens were divided into age-based groups (one group for each 
week of growth). During the waiting period for testing, the poultry received a balanced diet and water ad libitum.

\section{Image analysis using MT}

\section{Experimental arrangement for image acquisition}

The experimental setup consisted of a $150 \mathrm{~W}$ light source, a sinusoidal grid with a period projected of $0.2 \mathrm{~mm}$, a black painted vertical board and a digital camera (Figure 1).

The distance between the digital camera (Sony cyber-shot 5.1 mega pixels) and the screen $(\mathrm{H})$ was $2.15 \mathrm{~m}$, and the distance between the digital camera and light source (D) was $0.53 \mathrm{~m}$. The digital camera and light source were placed at different elevations from the ground with a relative elevation (h) of $0.1 \mathrm{~m}$, in order to observe the deformation of the grid out of the plane.

A grid was projected by the light source onto the black painted vertical board and covered an area of $0.4788 \mathrm{~m}^{2}$ (height of $0.57 \mathrm{~m}$ and length of $0.84 \mathrm{~m}$ ). The chicken was placed immediately in front of the screen to provide the best possible image contrast. Images of poultry with body mass (BM) were obtained by adjusting the digital camera with an optical zoom to $1.7 x$, which corresponds to a $1.0904 \mathrm{~m}^{2}$ capture area $(0.94 \mathrm{~m}$ of length and $1.16 \mathrm{~m}$ of height). This value of zoom was determined by evaluating image quality and processing capacity of the programs used.

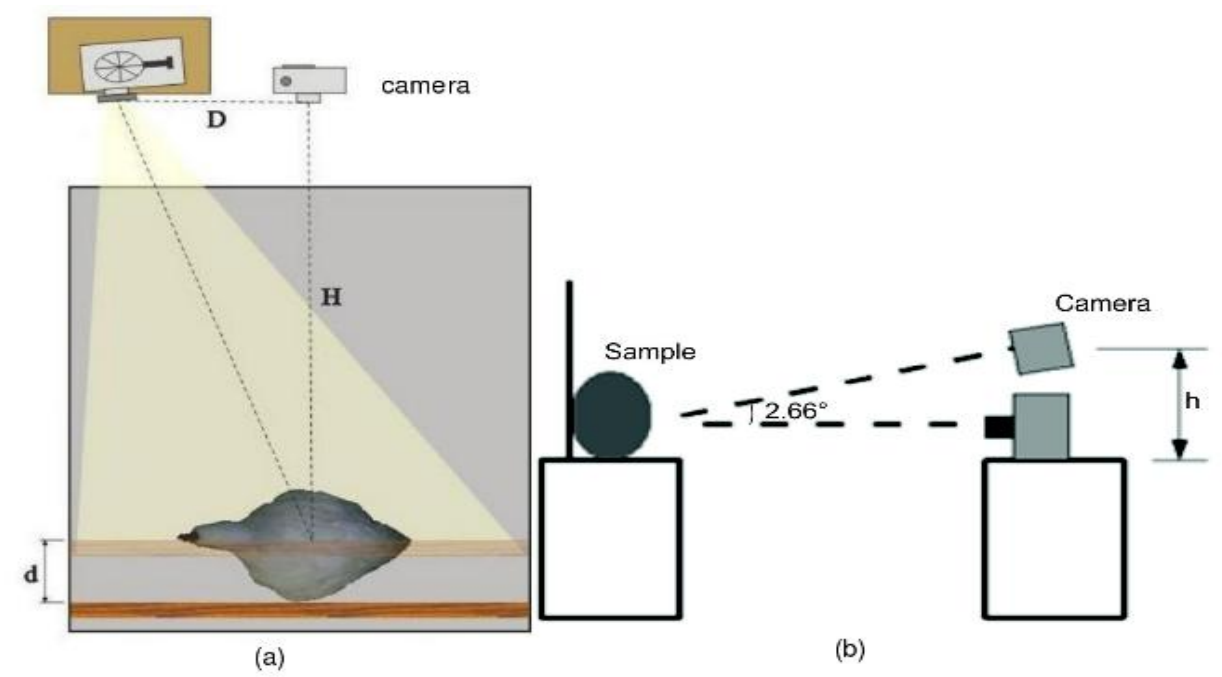

FIGURE 1. Experimental setup used for image acquisition, showing black painted vertical board moved by half of animal width, in (a) a top view, and in (b) a lateral view.

The grids were generated using AutoCAD ${ }^{\circledR} 2006$ (Autodesk, 2005), with spacing of $0.2 \mathrm{~mm}$ between fringes in order to produce a projection period of $0.2 \mathrm{~mm}$ in this set up. The grids were plotted on a translucent sheet with a resolution of $600 \mathrm{dpi}$. The grid was projected onto the chicken being characterized as the model reticulum $(R m)$.

Next, the grid was projected onto the vertical board, without the chicken, generating the reference reticulum $(R r)$. Subsequently, the screen was moved toward the digital camera by half the animal width (Figure 1). Captured images of the object and of the black painted vertical board are illustrated in Figures $2 \mathrm{a}$ and $2 \mathrm{~b}$, respectively. 


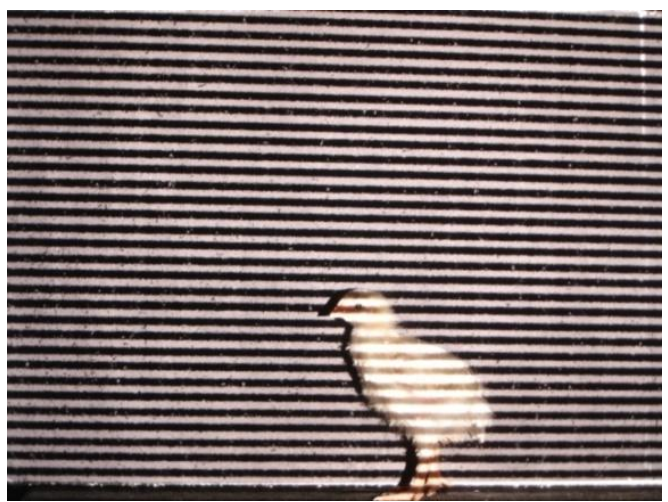

(a)

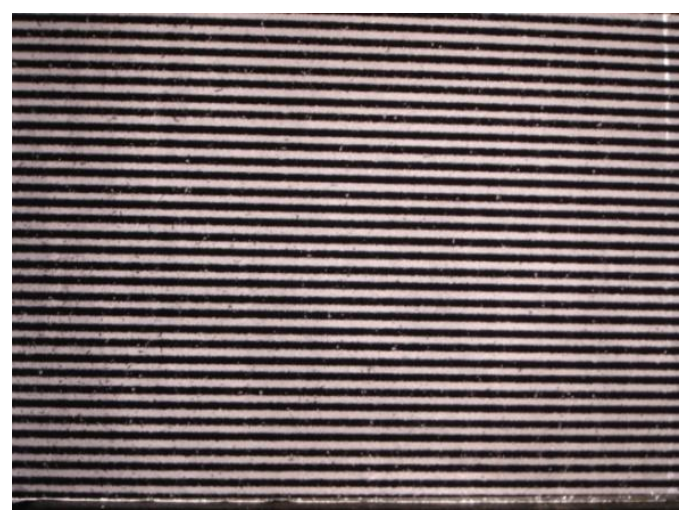

(b)

FIGURE 2. Examples of captured images of (a) chicken and (b) screen with grid projection.

\section{Processing images}

Captured images were processed using Microsoft ${ }^{\circledR}$ Paint through the phase shift process (Costa et al., 2008). To generate three-dimensional images of the chickens (Figure 3), pre-processed images were input to a function developed for Scilab ${ }^{\mathrm{TM}}$ (Scilab Image Processing toolbox, sourceforge.net/projects/siptoolbox) using the Gaussian filter to enhance images.

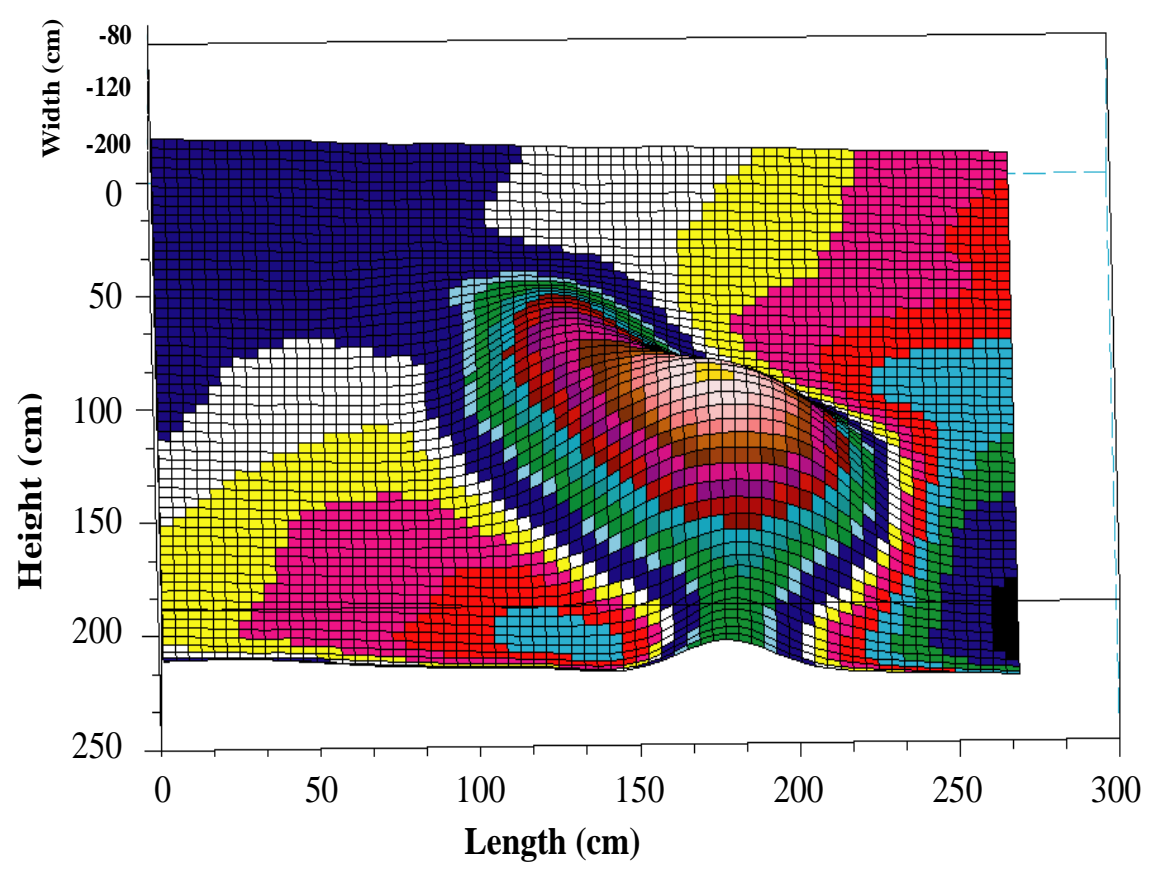

FIGURE 3. Poultry three-dimensional image processed by Scilab.

Surfer $^{\circledR}$ (Golden Software, Inc.) was used to determine the SA of broiler chickens. Coordinates corresponding to the length, height and width of poultry (generated by Scilab) were imported to Surfer ${ }^{\circledR}$. Next, the command Grid - Data was used to select the file generated in the previous step and to perform statistical tests of the $\mathrm{x}, \mathrm{y}$ and $\mathrm{z}$ columns.

A mesh of data was generated, which enabled the generation of a graphic containing isolines (Figure 4a). At this stage, the image contained surfaces that were not associated with the chicken. This surplus surface was removed from the map of isolines, providing a three-dimensional image of the poultry (Figure 4b), from which the SA was calculated. 


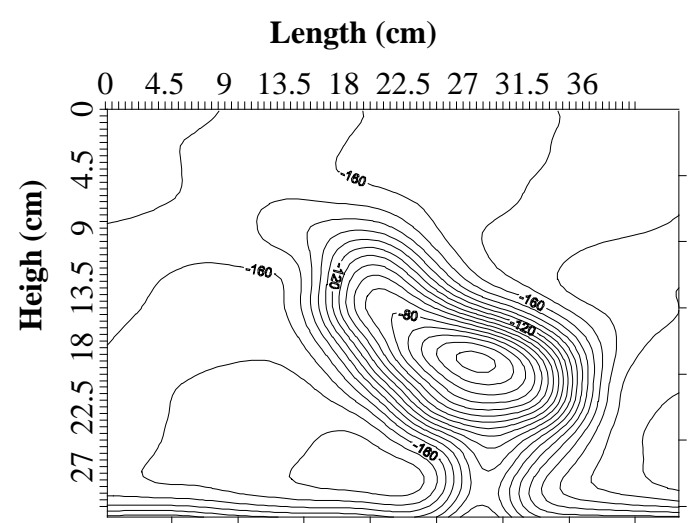

(a)

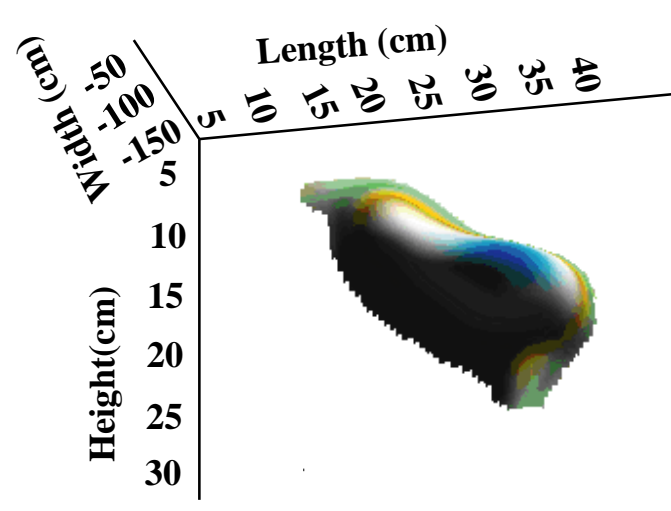

(b)

FIGURE 4. Broiler chicken (a) map with $\mathrm{x}$ - and y-axes and isolines and (b) three-dimensional image generated by Surfer ${ }^{\circledR}$ program.

\section{Conventional method}

The conventional method for broiler chicken SA determination was used as a reference to calibrate and validate the new MT-based method. In the conventional method, each chicken was submitted to an $8-12$ hour fast to prevent the food contained in the digestive tract from influencing their body mass (Mendes, 2001; Denadai et al. 2002). After fasting, chickens were weighed on a digital scale with an accuracy $\pm 0.05 \mathrm{~g}$. Images of the chickens were obtained using a digital camera applying MT. Next, chickens were sacrificed, and their skin and feathers were removed using a scalpel.

The skin with feathers was fixed with pins on a $1 \mathrm{~m} \times 1 \mathrm{~m}$ veneer plate. The plate was covered with black synthetic leather to provide contrast. Rulers, which served as a reference in digital image calibration, were placed alongside and perpendicularly to the plate. These rulers were also used to detect any distortion between the horizontal and vertical axes caused by the camera angle. Images of the skin were taken from a top view. A digital camera (Sony cyber-shot 5.1 mega pixels) with a maximum resolution of 5.1 mega pixels and $3 X$ of optical zoom was used for image acquisition. The images were then imported to AutoCAD ${ }^{\circledR} 2006$ (Autodesk, 2005) for SA calculation.

\section{Calibration}

MT calibration was performed using fifty-four chickens, male and female, distributed by weight and across all growth phases. Initially, images were processed without applying corrections and the surface areas were determined $\left(\mathrm{SA}_{\text {moiré }}\right)$. Next, the surface area was corrected $\left(\mathrm{SA}_{\text {moiré-ajusted }}\right)$ through an empirical model fitted based on the ratio of moiré area $\left(\mathrm{SA}_{\text {moiré }}\right)$ to actual area (obtained via experiment), and image processing was repeated with the adjusted model. The empirical model was fitted using the procedure PROC REG of the SAS ${ }^{\circledR}$ (2001). The model and their coefficients were tested through analysis of variance (F-test) and t-test, respectively. Correlation graph was used to verify how closely related two sets of data are (surface area values obtained by MT and that measured by conventional method, respectively).

\section{Validation}

After calibration, the MT was validated based on the surface areas of twelve chickens, both male and female. Surface area estimated by MT was compared to the values determined by the conventional method using a paired t-test. Again, correlation graph was used to verify how closely related two sets of data are (surface area values obtained by MT and that measured by conventional method, respectively). 


\section{RESULTS AND DISCUSSION}

After image analysis, data from twenty-two chickens (each with body mass less than $771.9 \mathrm{~g}$ ) were not used because constant motion of the young animals during the image acquisition phase resulted in blurred images. In addition, data from another twelve chickens (each with body mass greater than $771.9 \mathrm{~g}$ ) were discarded because of motion or because the chickens sat down during image acquisition. Thus, the MT calibration was effectively performed using twenty chickens.

The images were corrected according to Equation 1, fitted during the calibration process, showing a statistically significant (F test, $\mathrm{P}<0.0001)$ comparison of the actual areas with the moiré areas, with $\mathrm{R}^{2}$ of 0.9949 .

$$
\mathrm{SA}_{\text {moiré-ajusted }}=230.56 \pm 5.5 \mathrm{Ln}\left(\mathrm{SA}_{\text {moiré }}\right)-973.83 \pm 46.29
$$

After correction, it was verified through paired t-test that surface area values obtained by MT were not significantly different from those obtained by the conventional method (Figure 5). While the critical $t$ value was 2.02 the $t$ value was $5.35 \times 10^{-6}$. The error was $3.4 \%$. A strong positive correlation $(r=0.9949)$ was verified between the surface area values obtained by MT and that measured by conventional method.

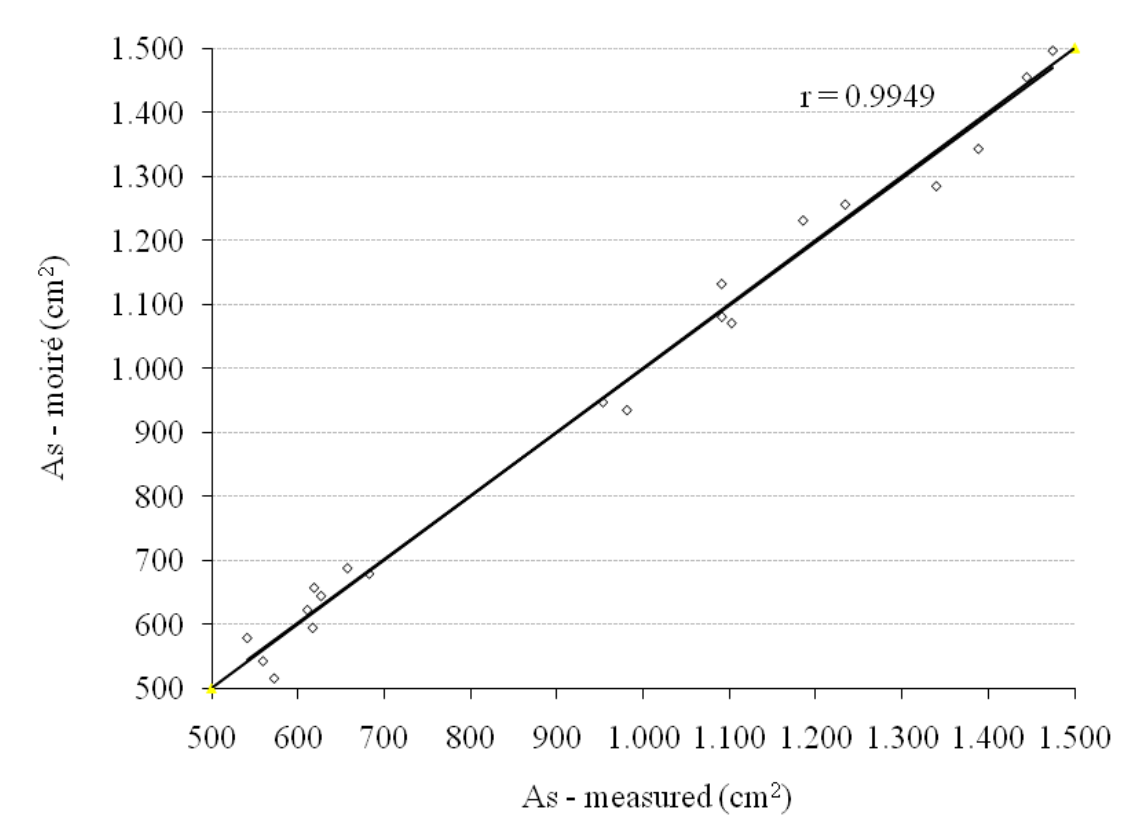

FIGURE 5. Comparison between surface area (SA) determined by the conventional method and SA determined by the moiré technique with application of correction factor.

Since the young chickens presented constant motion that causes noise in the images, MT validation was performed using twelve chickens, each with body mass equal or greater than 500.74 g. In the validation phase, there were no significant differences between the values of SA estimated by MT and those measured by the conventional method (paired t-test). While the critical $t$ value was 2.07 the $t$ value was 0.05 . The average error, considering the conventional method as a reference, was $47.65 \pm 23.80 \mathrm{~cm}^{2}$, which corresponded to $5.18 \%$ error. Figure 6 illustrates the positive strong correlation $(\mathrm{r}=0.9893)$ between the surface areas as determined through the two methods (moiré and conventional). 


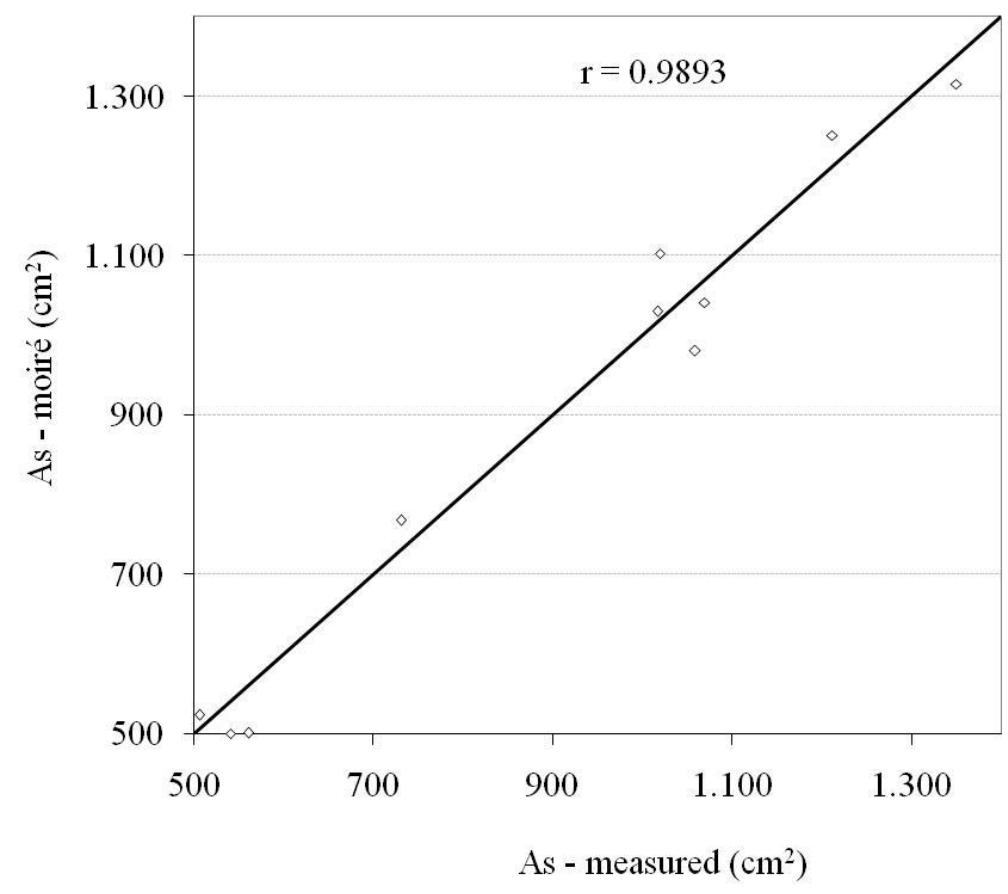

FIGURE 6. Comparison between surface areas of broiler chickens determined by the conventional method and the moiré technique.

Considering that the chicken's plumage has an irregular shape and that motion adds noise to the images, the mean measurement error of $5.18 \%$ is acceptable, especially considering that MT allows the animals to be measured non-destructively. Silva et al. (2007) fit an empirical equation to estimate a chicken's SA as a function of body mass, resulting in a mean estimation error of $4.68 \%$. Therefore, the error resulting from the use of moiré technique was within the range of the error for the conventional destructive method that used body mass, with the MT having the additional advantage of being able to quantify the shape of the animal.

The protocol presented here will facilitate the introduction of the projection moiré technique in to the poultry farming industry. However, technological innovation is needed to overcome some limitations, such as the stress of the chickens resulting from human manipulation. An alternative to the technique presented here is to arrange cameras to automatically acquire images as chickens pass through a walkway. This might overcome the problems related to unexpected motions of the chickens that were encountered in this experiment. The technique seems to be sufficiently robust for an industrial environment, since the challenges previously mentioned can be overcame, and the low errors presented here, for a non-destructive protocol, suggest that the MT technique is a reliable alternative to conventional destructive methods.

\section{CONCLUSIONS}

A feasible protocol for SA determination of broiler chickens using the moiré technique was presented. The proposed procedure exhibited $5.18 \%$ error compared to the conventional destructive method for SA determination. Problems with digitisation of young chickens with body mass less than $500 \mathrm{~g}$, were observed in the limited and stressful conditions associated with the manual image acquisition procedures.

\section{ACKNOWLEDGEMENTS}

The authors acknowledge FAPEMIG, CAPES, CNPq and Nogueira Rivelli Alimentos Company for support of this research. 


\section{REFERENCES}

AERTS, M.; WATHES, C.M.; BERCKMANS, D. Dynamic data-based modelling of heat production and growth of broiler chickens: development of an integrated management system. Biosystems Engineering, Harpenden, v.84, n.3, p.257-266, 2003.

ASUNDI, A.; YUNG, K.H. Logical moiré and its application. Experimental Mechanics, London, v.31, n.3, p.236-242, 1991.

AUTODESK. Autodesk inventor series: getting startted. San Rafael, 2005. v.10, 286 p.

BENOSTON. Moiré topography theory, San Raphael, 1997. Disponível em: <http:www.oet.gr/beneston / moiré.html>. Acesso em: 6 jul. 2006.

BRAGA, R.A.; OLIVEIRA, B.S.; COSTA, R.M.; LINO, A.C.L.; DALFABBRO, I.M. Suppression of border effects in moire techniques using three-dimensional methods. Biosystems Engineering, San Diego, v.102, n.1, p.1-8, 2009.

COSTA, R.M.; BRAGA, R.A.; OLIVEIRA, B.S.; SILVA, E.; YANAGI JÚNIOR, T.; LIMA, J. T. Sensitivity of the moiré technique for measuring biological surfaces. Biosystems Engineering, Harpenden, v.100, n.3, p.321-328, 2008.

DAL FABBRO, I.M.; MENDES, A.S.; RODRIGUES, S.; ALBIERO, D.; RABELO, G. F. Moiré supported physical characterization of chicken. In: INTERNATIONAL CONGRESS ON INFORMATION TECHNOLOGIES IN AGRICULTURE, FOOD AND ENVIRONMENT, 2., 2005, Adana. Anais... Adana: Cukurova University, 2005. p.246-250.

DENADAI, J.C.; MENDES, A.A.; GARCIA, R.G.; ALMEIDA, I.C.L.; MOREIRA, J.; TAKITA, T.S.; PAVAN, A.C.; GARCIA, E.A. Efeito da duração do período de jejum pré-abate sobre rendimento de carcaça e a qualidade da carne do peito de frangos de corte. Revista Brasileira de Ciência Avícola, Campinas, v.4, n.2, p.101-109, 2002.

FUNNELL, W.R.J.; DECRAEMER, W.F. Moiré shape measurements in eardrum models 1998. Disponível em: <http//Funs.biomed.mcgill.ca/não Funnell/Audilab/drunsh .html>. Accesso em: 18 may 2006.

HU, Q. 3-D Shape measurement techniques. Disponível em: <http://www.sinc.sunysb.edu/stu/qhu /Chapter1.htm>. Accesso em: 6 set. 2001.

KERATRON, C. Moiré fringe: comparing moiré fringes to Placido based topography. 2000. Disponívl em: <http://209.155.2.106/keratron.html>. Acesso em: 6 set. 2006.

KUO, C.T.; CHENG, S.C. 3D model retrieval using principal plane analysis and dynamic programming. Pattern Recognition Letters, Amsterdam, v.40, n.2, p.742-755, 2007.

MENDES, A.A. Jejum pré-abate em frangos de corte. Revista Brasileira de Ciência Avícola, Campinas, v.3, n.3, 2001.

NEUGEBAUER, H.; WINDISCHBAUER, G. Moiré topography in scoliosis research. In: BALLY, G. Von; GREGUSS, P. (Ed.). Optical in biomedical sciences. Berlin: Springer, 1982. p.250-253. (Spring Series In Optical Science, 20).

PARK, B.; LAWRENCE, K.C.; WINDHAM, W.R.; CHEN, Y.R.; CHÃO, K. Discriminant analysis of dual-wavelength spectral images for classifying poultry carcasses. Computers and Electronics in Agriculture, Amsterdam, v.33, n.3, p.219-231, 2002.

PRAKOONWIT, S.; BENJAMIN, R. 3 D surface point and wireframe reconstruction from multiview photographic images. Image and Vision Computing, Guildford, v.25, n.9, p.1.509-1.518, 2007. 
RAHMAN, A.; VON UNGE, M.; OLIVIUS, P.; DIRCKX, J.; HULTCRANTZ, M. Healing time, long-term result and effects of stem cell treatment in acute tympanic membrane perforation. International Journal of Pediatric Otorhinolaryngology, v.71, n.7, p.1.129-1.137, 2007.

SAS INSTITUTE. User's guide: release 8.2. Cary, 2001. 943 p.

SHITAKUBO, F.; FABRO, I.M.; LINO, L.A.O. Moiré interferometry applied to support fish. In: INTERNATIONAL CONGRESS ON INFORMATION TECHNOLOGY IN AGRICULTURE, FOOD AND ENVIROMENT, 1., 2003, Izmir. Proceedings... Izmir: Ege University/CIGR/AESEE/ TMMOB ZMO/ TUBITAK/ TBD, 2003. p.604-607.

SILVA, E.; YANAGI, T.; BRAGA, R.A.; LOPES, M.A.; DAMASCENO, F.A.; SILVA, G.C.A. Desenvolvimento e validação de um modelo matemático para o cálculo da área superficial de frango de corte. Engenharia Agrícola, Jaboticabal, v.29, n.1, p.1-7, 2009.

YANAGI JÚNIOR, T. Partial surface wetting to relieve acute thermal stress of laying hens. 2002. $93 \mathrm{f}$. Tese (Doutorado em Engenharia Agrícola) - Universidade Federal de Viçosa, Faculdade de Engenharia Agrícola e Ambiental, Viçosa, 2002.

YANAGI JÚNIOR, T.; DAMASCENO, G.S.; TEIXEIRA, V.H.; XIN, H. Prediction of black globe humidity index in poultry buildings. In: INTERNATIONAL LIVESTOCK ENVIRONMENT SYMPOSIUM, 6., 2001, Louisville. Proceedings... Louisville: ASAE, 2001. p.482-489.

YANAGI, J.T.; XIN, H.; GATES, R.; LEONARDO, F. Fuzzy logic model to predict laying hen body temperature rise during acute heat stress. In: CONGRESSO BRASILEIRO DE

ENGENHARIA AGRÍCOLA, 35., 2006, João Pessoa. Proceedings... João Pessoa: SBEA, 2006. 1 CD-ROM. 